Article

\title{
Oceanic Dimethyl Sulfide Emission and New Particle Formation around the Coast of Antarctica: A Modeling Study of Seasonal Variations and Comparison with Measurements
}

\author{
Fangqun $\mathrm{Yu} *$ and Gan Luo
}

Atmospheric Sciences Research Center, State University of New York, Albany, New York, NY 12203, USA; E-Mail: ganluo@asrc.cestm.albany.edu

* Author to whom correspondence should be addressed; E-Mail: yfq@ asrc.cestm.albany.edu; Tel.: +1-518-437-8767; Fax: 518-437-8758.

Received: 27 August 2010; in revised form: 12 November 2010 / Accepted: 2 December 2010 / Published: 6 December 2010

\begin{abstract}
A clear understanding of new particle formation processes in remote oceans is critical for properly assessing the role of oceanic dimethyl sulfide (DMS) emission on the Earth's climate and associated climate feedback processes. Almost free from anthropogenic pollutants and leafed plants, the Antarctic continent and surrounding oceans are unique regions for studying the lifecycle of natural sulfate aerosols. Here we investigate the well-recognized seasonal variations of new particle formation around Antarctic coastal areas with a recently developed global size-resolved aerosol model. Our simulations indicate that enhanced DMS emission and photochemistry during the austral summer season lead to significant new particle formation via ion-mediated nucleation (IMN) and much higher particle number concentrations over Antarctica and surrounding oceans. By comparing predicted condensation nuclei larger than $10 \mathrm{~nm}$ (CN10) during a three-year period (2005-2007) with the long-period continuous CN10 measurements at the German Antarctic station Neumayer, we show that the model captures the absolute values of monthly mean $\mathrm{CN} 10$ (within a factor 2-3) as well as their seasonal variations. Our simulations confirm that the observed Antarctic CN10 and cloud condensation nuclei $(\mathrm{CCN})$ seasonal variations are due to the formation of secondary particles during the austral summer. From the austral winter to summer, the zonally averaged CN10 and CCN in the lower troposphere over Antarctica increase by a factor of $\sim 4-6$ and $\sim 2-4$, respectively. This study appears to show that the $\mathrm{H}_{2} \mathrm{SO}_{4}-\mathrm{H}_{2} \mathrm{O}$ IMN mechanism is able to
\end{abstract}


account for the new particle formation frequently observed in the Antarctica region during the austral summer.

Keywords: DMS emission; nucleation; southern ocean; seasonal variations; CCN

\section{Introduction}

Aerosol precursor gases emitted from oceans have been well recognized to play an important role in the Earth's radiation budget and climate feedback processes. Oceanic dimethyl sulfide (DMS) is an important contributor to the global sulfur cycle and its oxidation accounts for $\sim 20 \%$ of the global $\mathrm{SO}_{2}$ sources [1]. Charlson et al. [2] proposed a negative feedback mechanism on the Earth's climate involving the oceanic DMS emission, sulfate aerosol production, and cloud properties (i.e., "CLAW" hypothesis). According to this hypothesis, a warmer climate would increase DMS emission and atmospheric DMS concentrations which in turn would lead to higher formation rates of sulfate aerosols and cloud condensation nuclei (CCN) abundance. The resulting increase in cloud albedo should reflect more sunlight back to space and thus cool the Earth. Despite numerous studies undertaken since 1987 to verify the "CLAW" hypothesis and understand its relevance to today's climate issues, the magnitude and even the sign of the "CLAW" feedback mechanism remains unclear [3-6]. A lack of quantitative understanding of new particle formation processes is one of many significant gaps in the "CLAW" hypothesis that remain to be resolved [6].

Almost free from anthropogenic pollution and leafed plants releasing organic aerosol precursors, the Antarctic continent and surrounding oceans are unique regions for studying natural atmospheric sulfate aerosols. The total number concentrations of particles in Antarctica have a strong seasonal variation, from as low as a few tens per $\mathrm{cm}^{3}$ in the austral winter (JJA: June, July, August) to several thousands per $\mathrm{cm}^{3}$ in the austral summer (DJF: December, January, February) [7-9]. Particle size distribution measurements indicate that the high DJF particle number concentrations are associated with the presence of nucleation mode particles [10-16]. Koponen et al. [14] reported particle size distributions (3-800 $\mathrm{nm}$ in diameter) measured in continental Antarctica during the austral summers 2000 and 2001 and showed that a nucleation mode (with diameter $<20 \mathrm{~nm}$ ) was present in more than a half of the measured spectra. It has been generally accepted that formation and growth of secondary particles in Antarctica is mainly through the oxidation product of DMS emitted from the Southern Oceans [17]. Particle chemical composition analyses suggest that accumulation mode particles in Antarctic air masses are mostly acidic and consist primarily of sulfuric acid [18,19].

While the presence of nucleation mode particles in Antarctic air during the austral summers has been well recognized, a comprehensive modeling study of the formation mechanisms of these particles is lacking. Ito et al. [11] discussed possible processes leading to new particle formation (binary, ternary, and ion nucleation) but no quantitative calculations were given. Park et al. [16] found that the $\mathrm{H}_{2} \mathrm{SO}_{4}$ concentrations $\left(\left[\mathrm{H}_{2} \mathrm{SO}_{4}\right]\right)$ measured at the South Pole during ISCAT 2000 are substantially below the values required for $\mathrm{H}_{2} \mathrm{SO}_{4}-\mathrm{H}_{2} \mathrm{O}$ binary homogeneous nucleation $(\mathrm{BHN})$ and suggested that either other species participated in particle formation and/or that the observed nucleation mode particles were transported from elsewhere. Koponen et al. $[13,14]$ found that new particle formation 
does take place in the Antarctic boundary layer and has apparently something to do with the coastal areas. Measurements onboard a ship indicated that a nucleation mode was frequently observed as the ship approached the Antarctic coast [13]. Based on particle size distributions (diameter 3-800 $\mathrm{nm}$ ) measured at the Finnish Antarctica research station Aboa $\left(73^{\circ} 03\right.$ ' S, $13^{\circ} 25^{\prime} \mathrm{W}, \sim 130 \mathrm{~km}$ from the coastline) during the austral summers 2000 and 2001, Koponen et al. [14] showed that evidence of recent new particle formation could be seen in marine/coastal air masses only. More recently, Virkkula et al. [19] and Asmi et al. [20] reported the observed size distributions of ion clusters and charged particles at Aboa during 12/14/2004-1/30/2005 and 12/29/2006-1/29/2007, and showed that clear nucleation events occurred on $\sim 21-23 \%$ of the days at the site, a fraction similar to that observed at a boreal forest site.

A number of modeling studies investigating new particle formation at a global scale have been reported in the last couple of years [17,21-28], although none of these studies specifically focused on new particle formation around the Antarctic coastal regions. Korhonen et al. [17] showed no nucleation in the boundary layer (BL) based on a BHN scheme and concluded that the main pathway of DMS influence on CCN number is the nucleation of DMS-derived $\mathrm{H}_{2} \mathrm{SO}_{4}$ in the free troposphere and subsequent downward entrainment. With the BL nucleation calculated by an empirical formula which expresses nucleation rate $\mathrm{J}$ as $\mathrm{J}=\mathrm{A}\left[\mathrm{H}_{2} \mathrm{SO}_{4}\right]$ (where $\mathrm{A}$ is an empirically derived constant), the studies of Merikanto et al. [26] and Wang and Penner [24] indicated significant contribution of BL nucleation to global particle number concentration and CCN abundance. Yu et al. [28] showed that the empirical formula significantly over-predict (by a factor of up to 10) the particle number concentrations in the BL over remote oceans. The extensive comparisons of simulated global particle number concentrations with land-, ship-, and aircraft- based measurements by Yu et al. [28] indicate that, among six widely used nucleation schemes involving $\mathrm{H}_{2} \mathrm{SO}_{4}$ vapor, only the ion-mediated nucleation (IMN) scheme can reasonably account for both absolute values (within a factor of $\sim 2$ ) and spatial distributions of particle number concentrations in the whole troposphere.

One major uncertainty in current global aerosol simulations remains to be the mechanism of new particle formation. As mentioned earlier, the Antarctic continent and surrounding oceans are unique regions for studying the formation of natural atmospheric sulfate aerosols. The purpose of this study is to investigate the seasonal variations of new particle formation around the Antarctic coastal areas associated with DMS emissions, using a recently developed global size-resolved aerosol model [27] and focusing on IMN mechanism. Multiple-year continuous measurements of CN10 at the coastal Antarctic station Neumayer are used, for the first time, to evaluate the ability of the model in capturing the season variations of $\mathrm{CN} 10$. The contributions of secondary and primary particles to $\mathrm{CCN}$ abundance in the region and their seasonal variations are also analyzed. This study is important in view of a possible large reduction in the DMS sea surface concentrations in the Southern Oceans (up to $\sim 40 \%$ ) in the year 2100 predicted by a global modeling study [5], and the unresolved physical processes governing the observed seasonal variations of cloud properties over the Southern Ocean [29-31].

\section{Global Size-resolved Aerosol Model}

$\mathrm{Yu}$ and Luo [27] incorporated an advanced particle microphysics (APM) model into GEOS-Chem, which is a global 3-D model of atmospheric composition driven by assimilated meteorological data 
from the NASA Goddard Earth Observing System 5 (GEOS-5). The GEOS-Chem model has been developed and used by many research groups and contains many state-of-the-art modules treating various chemical and aerosol processes [32-37] with up-to-date key emission inventories [38,39]. In GEOS-Chem, DMS emission by phytoplankton is calculated using a global distribution of DMS seawater concentrations from Kettle et al. [40] and a standard sea-air exchange parameterization driven by the local wind [41]. The global total DMS flux for 2006 based on GEOS-Chem is $20.0 \mathrm{Tg} \mathrm{S}$ $\mathrm{yr}^{-1}$, which is close to the values derived from most of the models discussed in Woodhouse et al. [42]. A detailed description of the GEOS-Chem (including various emission sources, chemistry and aerosol schemes) can be found on the model webpage [43].

In the present version of the APM module, size-resolved microphysics for secondary particles (i.e., those formed from gaseous species) and sea salt have been treated with 40 sectional bins to represent sulfate (or secondary) particles and 20 sectional bins to represent sea salt particles. The bin structure is chosen to have relatively high resolution for the size ranges important to the growth of nucleated particles (a few nanometers) to CCN (30 bins in the dry diameter range of $1.2 \mathrm{~nm}-120 \mathrm{~nm}$ ). The dust particles are represented by four bins. Both black carbon and primary organic carbon particles are represented with two log-normal modes. The growth of nucleated particles through the condensation of sulfuric acid vapor and equilibrium uptake of nitrate, ammonium, and secondary organic aerosol (SOA) is explicitly simulated, along with the coagulation scavenging of secondary particles by primary particles (dust, black carbon, organic carbon, and sea salt). The model also keeps track of the amount of secondary species coated on each type of primary particles, as a result of coagulation, condensation, and equilibrium uptake. More details of the aerosol model can be found in Yu and Luo [27].

In this work, we extend the studies presented in Yu and Luo [27] by carrying out simulations with a horizontal resolution of $2^{\circ} \times 2.5^{\circ}$ and 47 vertical layers up to 0.01 hpa (GEOS-5 meteorological fields). Our previous publications focus on the discussions of annual mean global aerosol number abundance simulated with GEOS-Chem + APM at $4^{\circ} \times 5^{\circ}$ horizontal resolution. This study focuses on seasonal variations of new particle formation over Antarctica and surrounding ocean simulated with GEOSChem $+\mathrm{APM}$ at $2^{\circ} \times 2.5^{\circ}$ horizontal resolution. The GEOS-Chem v8-01-03 used in Yu and Luo [27] has been updated to v8-02-02 for the present simulation. New particle formation is calculated based on an ion-mediated nucleation mechanism [44] which has been shown to reasonably account for total number concentrations of particles larger than $\sim 4 \mathrm{~nm}$ and $\sim 10 \mathrm{~nm}$ observed in different parts of the troposphere [27,28]. The oceanic isoprene and $\alpha$-pinene emission indicated by ship measurements is not considered in the present study due to the large unresolved difference between the total fluxes derived from "top-down" and "bottom-up" approaches [45]. We have conducted simulations for three years (2005-2007), with 2 months of spin-up running. The seasonally mean results presented below are for year 2006 only. Sensitivity studies to examine the impact of DMS emission change and role of BHN have also been carried out for year 2006.

\section{Simulations and Results}

\subsection{General Features}

Figure 1 shows the simulated seasonally-averaged DMS emission rate, $\mathrm{SO}_{2}$ concentration $\left(\left[\mathrm{SO}_{2}\right]\right)$, $\mathrm{H}_{2} \mathrm{SO}_{4}$ gas photochemical production rate $\left(\mathrm{P}_{\mathrm{H} 2 \mathrm{SO}}\right)$, and $\left[\mathrm{H}_{2} \mathrm{SO}_{4}\right]$ for the austral summer (DJF) and 
winter (JJA) seasons in the surface layer over Antarctica and the surrounding ocean. Due to the sea ice formation, DMS emission near the coastal regions $\left(\sim 65^{\circ} \mathrm{S}\right.$ and South) is essentially zero in the winter (JJA). The melting of ice during DJF leads to significant DMS emission, with a rate exceeding $30 \mathrm{mg}$ $\mathrm{m}^{-2}$ month $^{-1}$ near the western Antarctic coastal regions. In most parts of the Southern Ocean, DMS emission rates during the austral summer are a factor of 3-10 higher than those during the austral winter. As a result of higher DMS emission and stronger photochemistry associated with the increased sunlight, $\left[\mathrm{SO}_{2}\right], \mathrm{P}_{\mathrm{H} 2 \mathrm{SO}}$, and $\left[\mathrm{H}_{2} \mathrm{SO}_{4}\right]$ concentrations are enhanced significantly in the austral summer season. Seasonal mean $\left[\mathrm{SO}_{2}\right]$ during DJF can reach over $100 \mathrm{ppt}, \mathrm{P}_{\mathrm{H} 2 \mathrm{SO} 4}$ over $1000 \mathrm{~A} \mathrm{~cm}^{-3} \mathrm{~s}^{-1}$, and $\left[\mathrm{H}_{2} \mathrm{SO}_{4}\right]$ over $1.2 \times 10^{6} \mathrm{~cm}^{-3}$ around the western Antarctica coastal regions. In contrast, seasonal mean [SO $\mathrm{SO}_{2}$ ] during JJA is below $15 \mathrm{ppt}, \mathrm{P}_{\mathrm{H} 2 \mathrm{SO} 4}$ below $10 \mathrm{~cm}^{-3} \mathrm{~s}^{-1}$, and $\left[\mathrm{H}_{2} \mathrm{SO}_{4}\right]$ below $4 \times 10^{5} \mathrm{~cm}^{-3}$ in the surface layer over Antarctica and the Southern Ocean.

The enhanced DMS emission, photochemistry, and $\left[\mathrm{H}_{2} \mathrm{SO}_{4}\right]$ lead to significant new particle formation and much higher total particle number concentrations in the surface layer over Antarctica and the surrounding ocean during the Austral summer season, which can be clearly seen in Figure 2. It is interesting to note that the predicted highest nucleation rates are confined around the coastline (Figure 2a), which is consistent with measurements [13,14]. Our model reveals that the association of nucleation with coastal areas is a result of high $\mathrm{P}_{\mathrm{H} 2 \mathrm{SO} 4}$ (Figure 1e), relatively lower condensation sink (CS) (not shown), and high $\left[\mathrm{H}_{2} \mathrm{SO}_{4}\right]$ (Figure $1 \mathrm{~g}$ ) in these regions. In the surface layer over most parts of the Southern Ocean, nucleation rates are small because of relatively lower $\left[\mathrm{H}_{2} \mathrm{SO}_{4}\right]$ caused by high surface areas associated with increased sea salt particles. The seasonal mean concentration of the condensation nuclei larger than $3 \mathrm{~nm}(\mathrm{CN} 3)$ reaches above $\sim 2000 \mathrm{~cm}^{-3}$ in the surface layer around the coastal areas during the austral summer season, with large horizontal gradients around the coastline. This is in dramatic contrast with those of the winter season where CN3 is generally in the range of $50-200 \mathrm{~cm}^{-3}$ and increases with decreasing latitude. There also exist significant seasonal variations of the number concentration of condensation nuclei larger than $10 \mathrm{~nm}(\mathrm{CN} 10)$ and $\mathrm{CCN}$ at water supersaturation of $0.4 \%$ (CCN0.4, corresponding to dry diameter of $\sim 60 \mathrm{~nm}$ ). The seasonal mean CN10 and CCN0.4 in the surface layer over the Antarctic and coastal regions are respectively in the range of 300-1500 $\mathrm{cm}^{-3}$ and $60-200 \mathrm{~cm}^{-3}$ during the austral summer, and are respectively in the range of $50-150 \mathrm{~cm}^{-3}$ and $20-60 \mathrm{~cm}^{-3}$ during the austral winter. Compared to $\mathrm{CN} 10$, the relatively higher CCN0.4 seen over the Southern Ocean for both seasons (especially the winter season) are due to the high sea salt particle emissions. 
Figure 1. Simulated seasonal averages of (for year 2006) DMS emission rate, $\mathrm{SO}_{2}$ concentration ([SO $\left.\left.\mathrm{SO}_{2}\right]\right), \mathrm{H}_{2} \mathrm{SO}_{4}$ gas photochemical production rate $\left(\mathrm{P}_{\mathrm{H} 2 \mathrm{SO} 4}\right)$, and $\mathrm{H}_{2} \mathrm{SO}_{4}$ gas concentration $\left(\left[\mathrm{H}_{2} \mathrm{SO}_{4}\right]\right)$ during the austral summer (DJF) and winter (JJA) seasons in the surface layer over Antarctica and surrounding oceans. The location of the German Neumayer station $\left(70^{\circ} 40^{\prime} \mathrm{S}, 008^{\circ} 16^{\prime} \mathrm{W}\right)$ is marked with " $\mathrm{X}$ " in each panel.

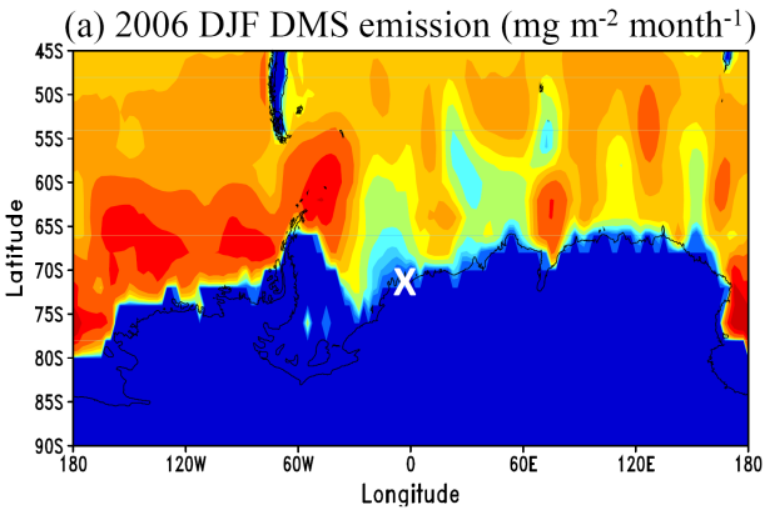

(c) 2006 DJF surface layer $\mathrm{SO}_{2}(\mathrm{ppt})$

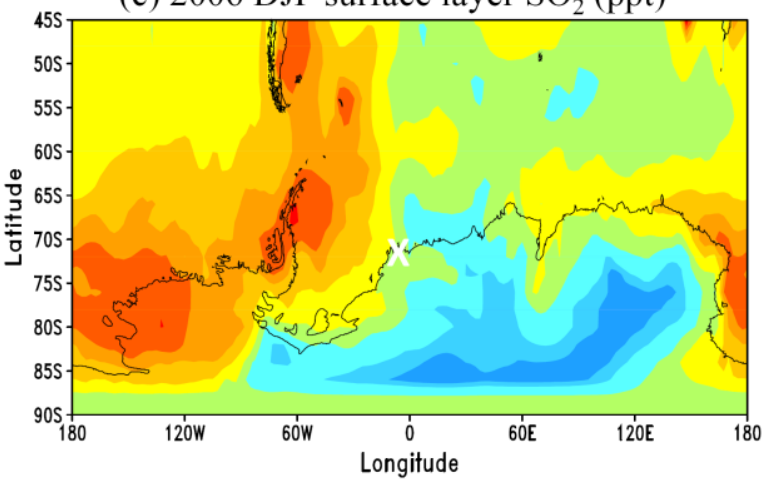

(e) 2006 DJF surface layer $\mathrm{PSO}_{4}\left(\# \mathrm{~cm}^{-3} \mathrm{~s}^{-1}\right)$
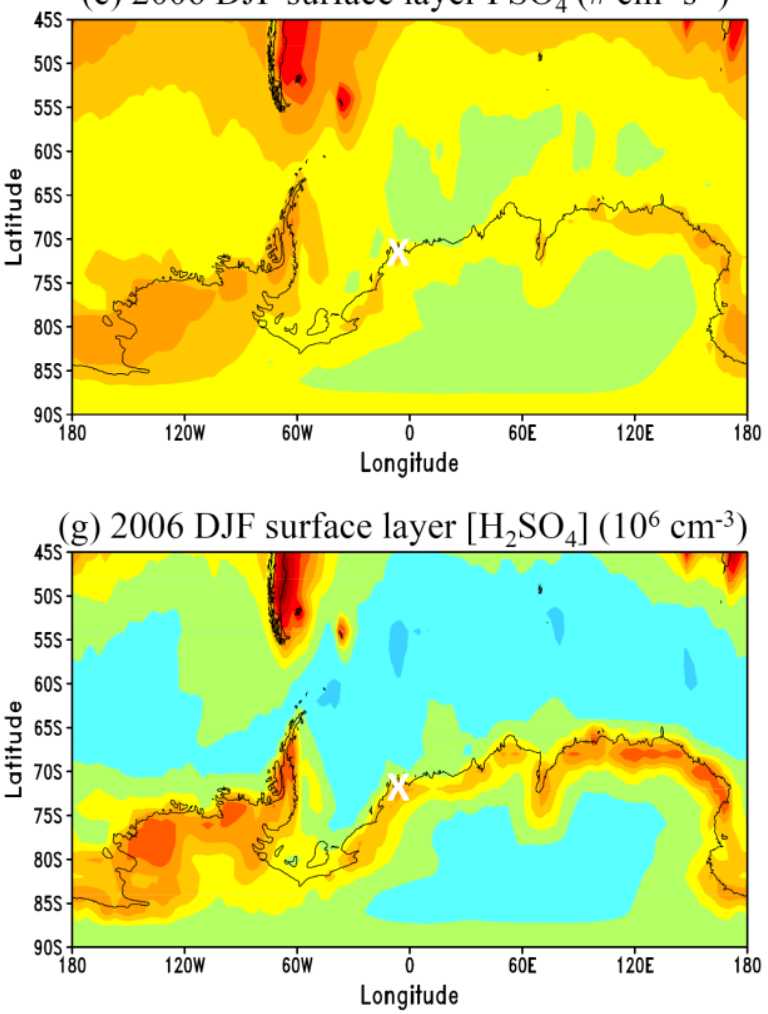

(b) 2006 JJA DMS emission $\left(\mathrm{mg} \mathrm{m}^{-2}\right.$ month $\left.^{-1}\right)$

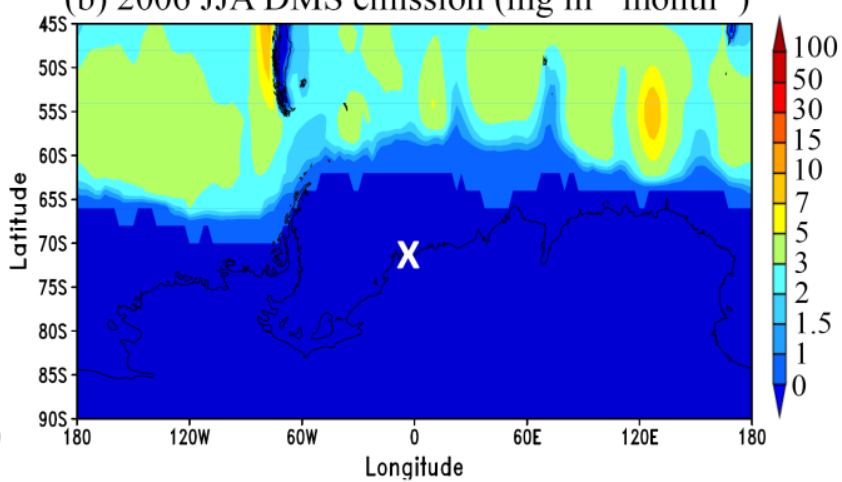

(d) 2006 JJA surface layer $\mathrm{SO}_{2}$ (ppt)

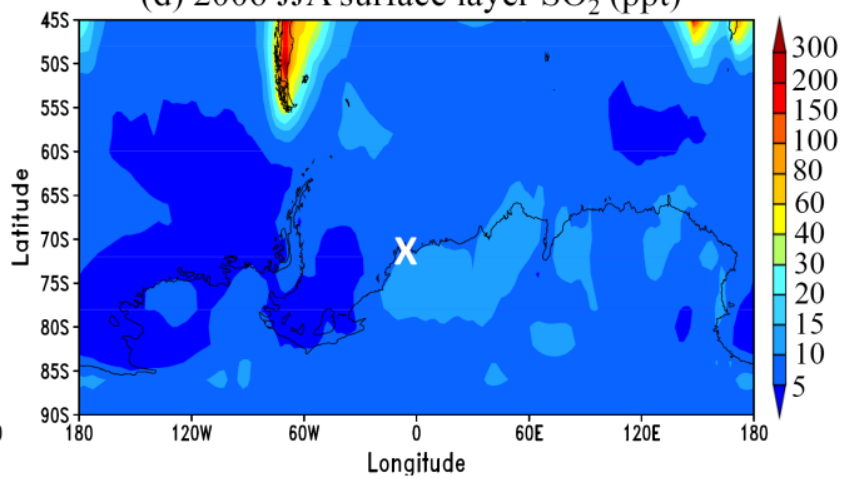

(f) 2006 JJA surface layer $\mathrm{PSO}_{4}\left(\# \mathrm{~cm}^{-3} \mathrm{~s}^{-1}\right)$
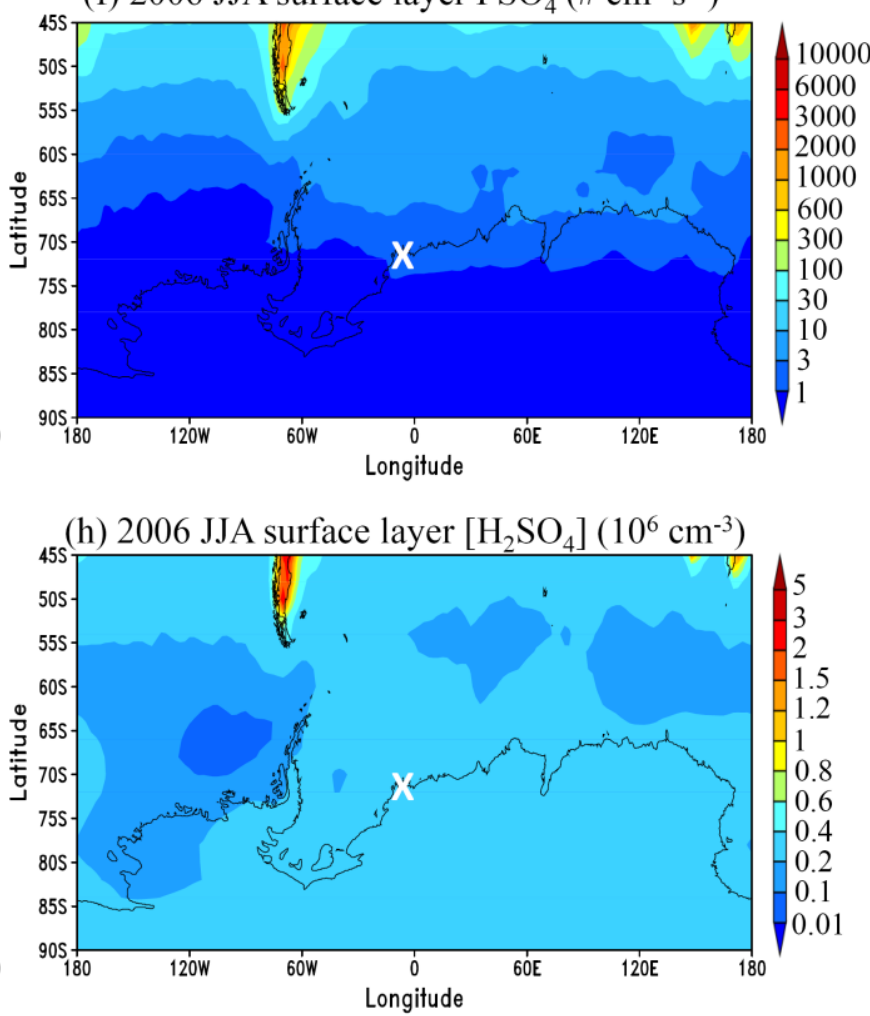
Figure 2. Simulated IMN rate (JIMN), total concentrations of the condensation nuclei larger than $3 \mathrm{~nm}(\mathrm{CN} 3)$ and $10 \mathrm{~nm}(\mathrm{CN} 10)$, and total concentrations of $\mathrm{CCN}$ at water supersaturation of $0.4 \%$ (CCNO.4) during the austral summer (DJF) and winter (JJA) seasons (seasonally-averaged for year 2006) in the surface layer over Antarctica and surrounding oceans. The location of the German Neumayer station $\left(70^{\circ} 40^{\prime} \mathrm{S}, 008^{\circ} 16^{\prime} \mathrm{W}\right)$ is marked with " $\mathrm{X}$ " in each panel.
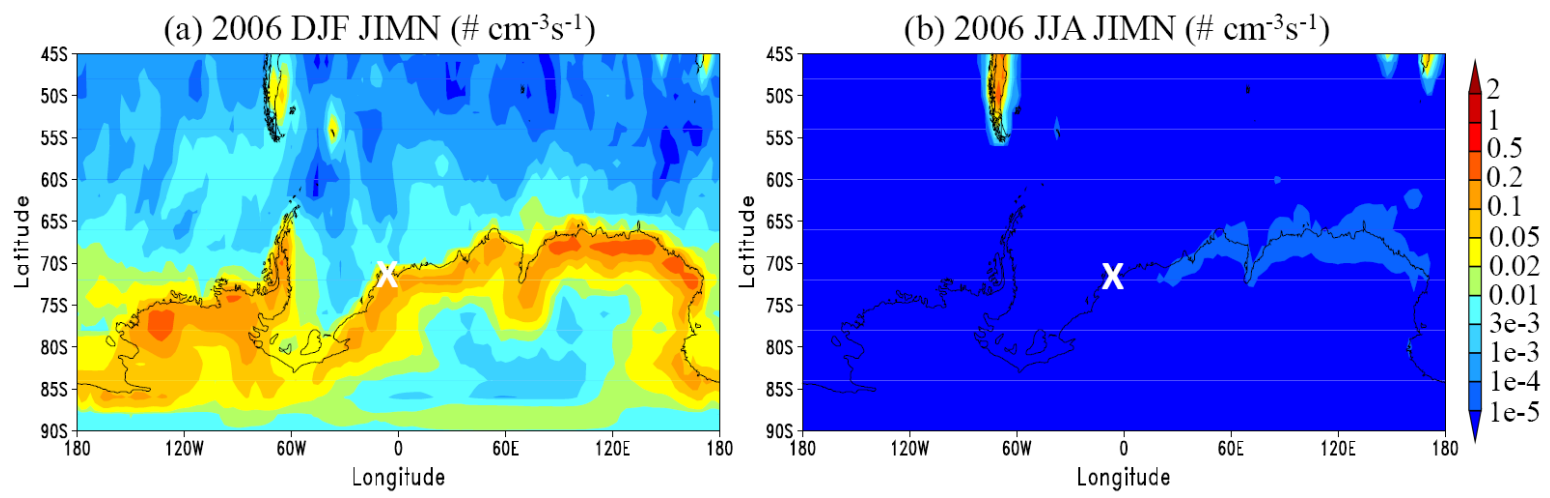

(c) 2006 DJF Total CN3 (\# $\left.\mathrm{cm}^{-3}\right)$

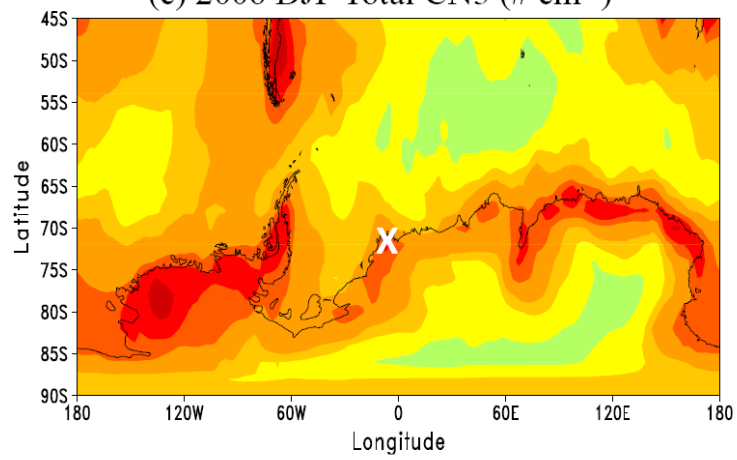

(d) 2006 JJA Total CN3 $\left(\# \mathrm{~cm}^{-3}\right)$

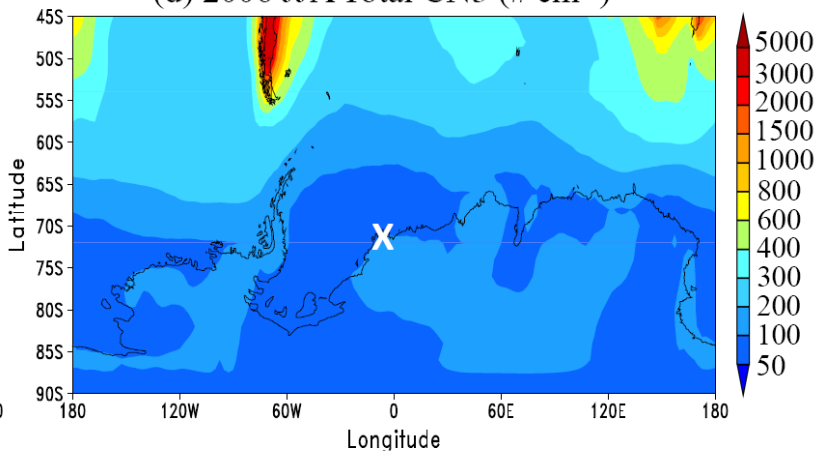

(e) 2006 DJF Total CN10 (\# $\left.\mathrm{cm}^{-3}\right)$
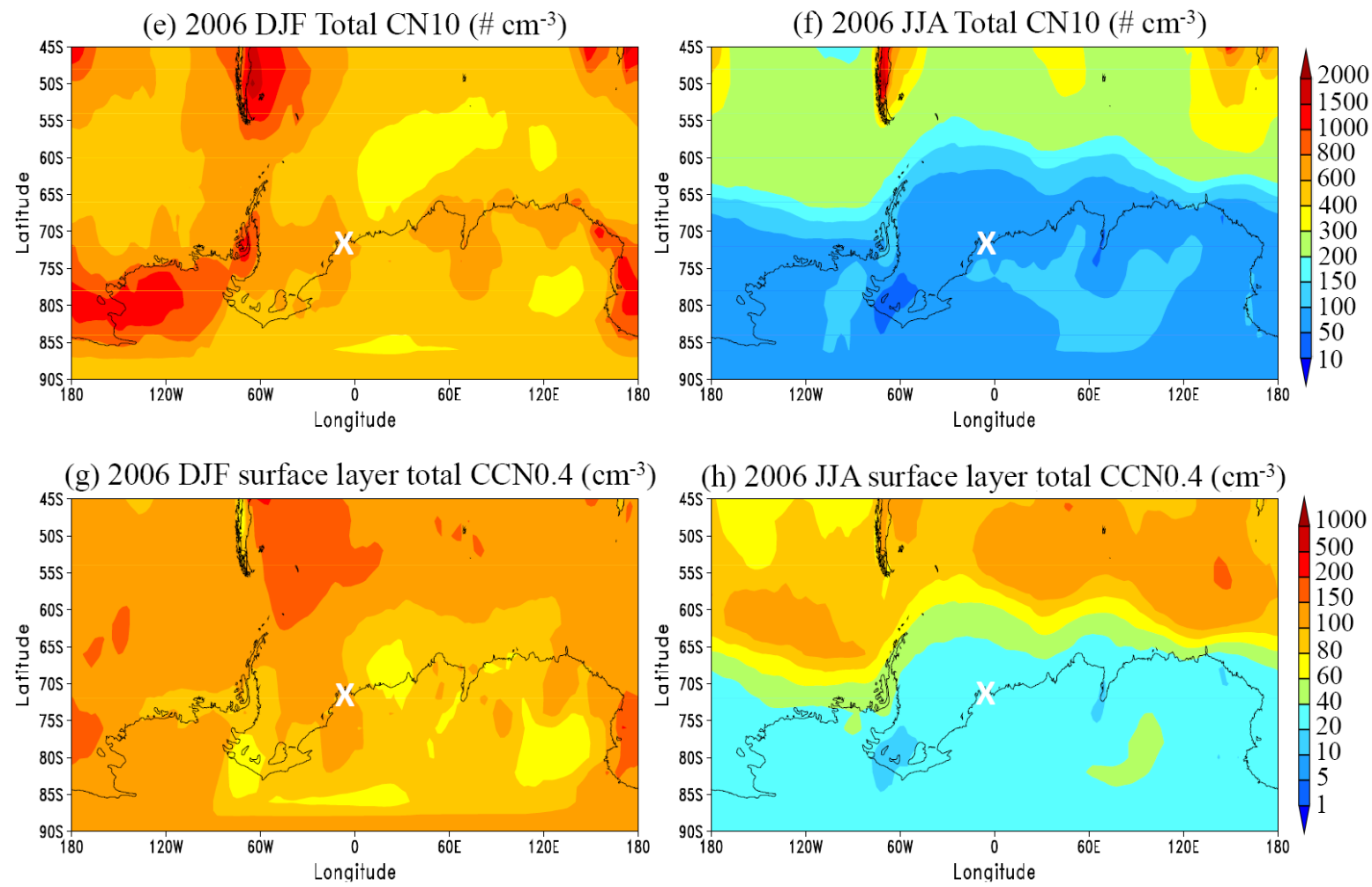


\subsection{Comparison to Long-term Measurements}

As mentioned in the Introduction, significant seasonal variations of new particle formation and particle number concentration have been observed in Antarctica. CN10 has been continuously measured at the German Antarctic station Neumayer (7040’S, $008^{\circ} 16^{\prime} \mathrm{W}$ ) [46] since 1993. The coastal Antarctic station Neumayer is $42 \mathrm{~m}$ above sea level and situated on the Ekstrom Ice Shelf and about $5 \mathrm{~km}$ from the southeast part of Atka Bay. More detailed information about the station and CN10 measurements can be found in König-Langlo et al. [47] and Weller and Lampert [48]. The long-term continuous CN10 measurements can be used to assess the ability of the model in capturing the main processes controlling particle formation and concentrations in the region. Figure 3 presents the simulated monthly mean $\left[\mathrm{SO}_{2}\right], \mathrm{CS}, \mathrm{P}_{\mathrm{H} 2 \mathrm{SO}},\left[\mathrm{H}_{2} \mathrm{SO}_{4}\right]$, JIMN, CN3, CN10, and CCN0.4 during a 3-year period (2005/01-2007/12) at the Neumayer station. The daily and monthly mean CN10 data from the Neumayer station are plotted in Figure $3 \mathrm{c}$ for comparison. In addition to total CN10 and CCN0.4, the contributions of primary particles (including sea salt, BC, POC, and dust) to CN10 and CCN0.4 are also shown in Figure 3c and Figure 3d.

It is clear from Figure $3 \mathrm{c}$ that the model captures the absolute values of monthly mean CN10 (within a factor of 2-3) as well as their seasonal variations, with a Pearson correlation coefficient of 0.87 and normalized mean bias of -0.037 . We can see that both model and observations indicate around a factor of 7 increase in monthly mean CN10 from July (3-year average of $82 \mathrm{~cm}^{-3}$ and $82 \mathrm{~cm}^{-3}$ for observation and model, respectively) to January (3-year average of $537 \mathrm{~cm}^{-3}$ and $595 \mathrm{~cm}^{-3}$ for observation and model, respectively). Our model simulations clearly indicate that the observed CN10 seasonal variations are due to the formation of secondary particles (via IMN) during the austral summer associated with enhanced $\mathrm{H}_{2} \mathrm{SO}_{4}$ production and $\left[\mathrm{H}_{2} \mathrm{SO}_{4}\right]$ (Figure $3 \mathrm{a}, 3 \mathrm{~b}$ ). Primary particles (dominated by sea salt particles in the region) contribute $\sim 30 \mathrm{~cm}^{-3}$ to total particle number concentrations and there are no obvious seasonal variations (Figure 3c, 3d). The peak monthly mean $\left[\mathrm{H}_{2} \mathrm{SO}_{4}\right]$, JIMN, and total concentration of particles larger than $3 \mathrm{~nm}(\mathrm{CN} 3)$ at the station reach $\sim 1-1.5$ $\times 10^{6} \mathrm{~cm}^{-3}, \sim 100-300 \mathrm{~cm}^{-3} \mathrm{hr}^{-1}$, and $\sim 1000-3000 \mathrm{~cm}^{-3}$, respectively. The rate of $\mathrm{H}_{2} \mathrm{SO}_{4}-\mathrm{H}_{2} \mathrm{O}$ IMN around Antarctica, which is lower than those in the regions under the influence of anthropogenic $\mathrm{SO}_{2}$ emission, is significant enough to cause clear seasonal variations in particle number concentrations. The good agreement of predicted seasonal variations of CN10 based on the IMN mechanism with measurements during three simulated years at the remote site free from anthropogenic pollution and leafed plants is in support of the IMN mechanism. Based on the observed evolution of the ion mobility spectrum at the Finnish Antarctica research station Aboa [19,20], ions (especially negative ions) were clearly involved in the nucleation. Asmi et al. [20] estimated that IMN contributes up to $30 \%$ of observed nucleation rates. However, as pointed out in Yu [44], the real contribution of IMN to nucleation is likely larger because the growth of neutral clusters $<2 \mathrm{~nm}$ resulting from ion-ion recombination (an important channel of IMN [49]) is treated as neutral nucleation in Asmi et al. [20]'s estimation. This study appears to show that the present IMN mechanism, which is based on state-ofthe-art thermodynamic and laboratory data [44], can reasonably account for the new particle formation frequently observed in the Antarctica region during the austral summer.

As a result of secondary particle formation and growth, the monthly mean CS (Figure 3a) and CCN0.4 (Figure 3d) at the Neumayer station increases from $\sim 2 \times 10^{-4} \mathrm{~s}^{-1}$ and $\sim 25-30 \mathrm{~cm}^{-3}$ in the 
austral winter to $\sim 4 \times 10^{-4} \mathrm{~s}^{-1}$ and $75-130 \mathrm{~cm}^{-3}$ in the austral summer. In the surface layer at the Neumayer station, secondary particles appear to contribute $\sim 40 \%$ to total CCN0.4 in the winter and $>70 \%$ in the summer. Only a very small fraction of secondary particles $(<5 \%)$ can serve as CCN0.4 in the summer because of their small sizes. It should be noted that the current study doesn't consider the oceanic VOC emissions because of large uncertainty in the estimated emission rates [45]. Depending on the strength of the oceanic VOC emission, the oxidation product of VOC may substantially enhance the growth rate of nucleated particles and hence CCNO.4 in the Antarctic and the Southern Ocean regions during the austral summer months. Further research is needed to quantify the oceanic VOC emission and its impact on the concentration of climate effective aerosols. We also noticed from Figure $3 \mathrm{c}$ that the model under-predicts the CN10 in August and September (by 30$60 \%$ ) for all three years. The reasons for the under-prediction remain unclear but could be caused by the uncertainty in the emission, meteorology, microphysics, and transport.

Figure 3. Simulated monthly mean $\left[\mathrm{SO}_{2}\right], \mathrm{CS}, \mathrm{P}_{\mathrm{H} 2 \mathrm{SO}},\left[\mathrm{H}_{2} \mathrm{SO}_{4}\right], \mathrm{JIMN}, \mathrm{CN} 3, \mathrm{CN} 10$, and CCN0.4 during a 3-year period (2005/01-2007/12) at the Neumayer station $\left(70^{\circ} 40\right.$ 'S, $\left.008^{\circ} 16^{\prime} \mathrm{W}\right)$. The daily and monthly mean CN10 data from the German Antarctic station Neumayer are plotted in Figure $3 \mathrm{c}$ for comparisons. In addition to total CN10 and CCN0.4, the contributions of primary particles (including sea salt, BC, POC, and dust) to CN10 and CCN0.4 are also shown in Figures 3c and 3d.
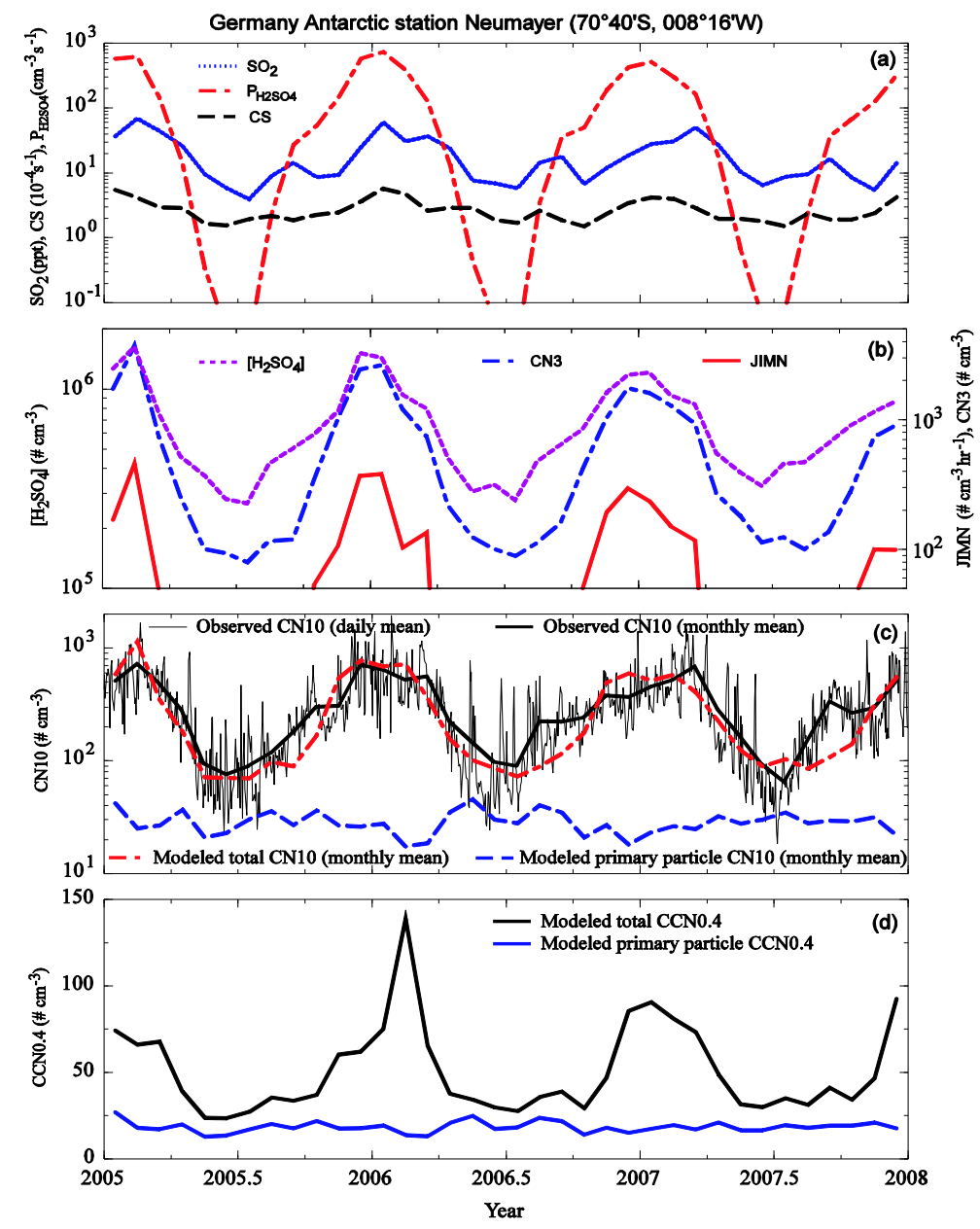


\subsection{Vertical Profiles}

So far our discussions have been limited to the surface layer. To look into how the formation of secondary particles during the austral summer may affect the $\mathrm{CN}$ and $\mathrm{CCN}$ abundance at higher altitude, we plot the zonally averaged vertical distributions of relevant key parameters resolved in our model. Figure 4 show the seasonal mean vertical structures of JIMN, total CN10, CCN0.4 total and CCN0.4 associated with sea-salt particles over the Antarctica and the Southern Ocean region (45 S and south) for DJF and JJA. It is clear from Figure 4 that significant new particle formation in the austral summer extends from boundary layer to $\sim 500 \mathrm{mb}$. High concentrations of sea salt particles over the Southern Ocean are generally confined to the marine boundary layer (MBL) and there is no obvious seasonal variation in sea salt particle concentration at different altitudes (Figure $4 \mathrm{~g}, 4 \mathrm{~h}$ ). Although nucleation is inhibited in the MBL over the Southern Ocean due to the high concentration of sea salt particles (Figure 4g), significant nucleation occurs above the MBL (Figure 4a). JIMN, CN10, and total CCN0.4 at all altitudes in the region have lowest values over the Antarctica during the austral winter season but generally have highest values over Antarctica during the austral summer season. The peak DJF-averaged JIMN, CN10, and total CCN0.4 values exceed $0.1 \mathrm{~cm}^{-3} \mathrm{~s}^{-1}, 800 \mathrm{~cm}^{-3}$, and $150 \mathrm{~cm}^{-3}$, respectively. As a result of the secondary particle formation during the austral summer (DJF), the zonally averaged CN10 and CCN0.4 over Antarctica increase by a factor of 4-6 and 2-4 (compared to those in JJA), respectively.

\subsection{Sensitivity Study: Impact of DMS Emission Variation and Contribution of BHN}

DMS emission rates and nucleation mechanisms are two of major uncertainties in current studies of new particle formation around the Antarctica. DMS emission rates have large spatial and temporal variations [42] and future climate change may significantly affect DMS emission in the Southern Oceans [5]. BHN has been widely employed to calculate new particle formation rate in previous global studies $[17,24,26]$. Here we carry out sensitivity study to examine the impact of DMS emission variation on Antarctic $\mathrm{CN} 10$ and the contribution of BHN. The empirical activation nucleation formula $\left(\mathrm{J}=\mathrm{A}\left[\mathrm{H}_{2} \mathrm{SO}_{4}\right]\right)$, while has also been used in previous modeling studies to predict particle formation in the BL [24,26], is not examined here because of its known significant over-prediction of marine BL particle number concentration (by up to one order of magnitude) and large range (up to 4 orders of magnitude) in the value of pre-factor A derived from different field measurements [28].

In addition to the baseline case (Case_baseline) presented in Figures 1 to 4, simulations of three sensitivity study cases have been carried for year 2006 (after two months of spin-up): (1) baseline DMS emission is scaled by 1.4 (Case_DMS1.4); (2) baseline DMS emission is scaled by 0.6 (Case_DMS0.6), (3) BHN scheme of Yu [50] (instead of IMN scheme) is used (Case_BHN). Table 1 and Figure 5 compare $\mathrm{CN} 10$ values observed and predicted in different cases for different months of 2006 at the Neumayer station. Pearson correlation coefficient (r) and normalized mean bias (NMB) for four different modeling cases are also given in Table 1 . 
Figure 4. Seasonal means of zonally averaged vertical (sigma $=$ pressure/surface pressure) structures of JIMN, total CN10, CCN0.4 total and CCN0.4 associated with sea salt particles over the Antarctica and the Southern Ocean regions ( $45^{\circ} \mathrm{S}$ and south) for DJF and JJA.

(a) 2006 DJF JIMN $\left(\# \mathrm{~cm}^{-3} \mathrm{~s}^{-1}\right)$

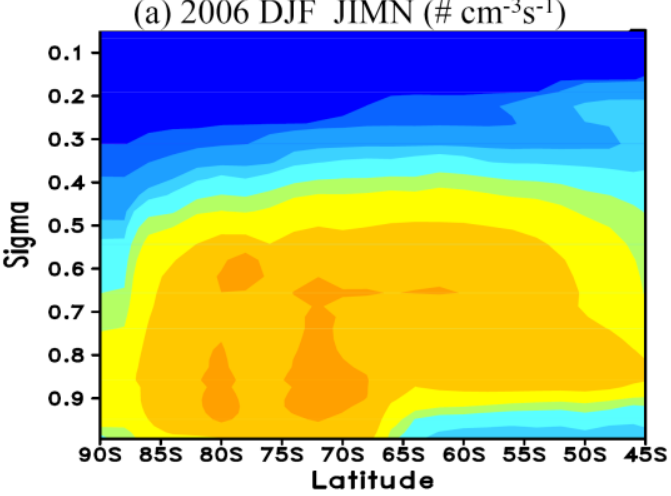

(c) 2006 DJF total CN10 $\left(\# \mathrm{~cm}^{-3}\right)$

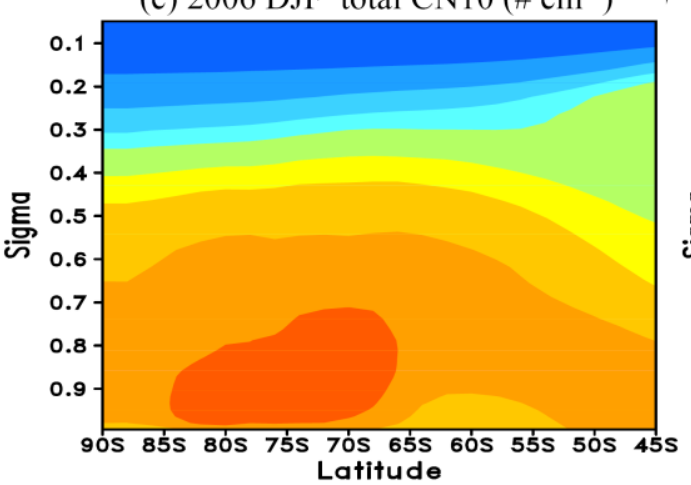

(e) 2006 DJF total CCN10.4 $\left(\# \mathrm{~cm}^{-3}\right)$

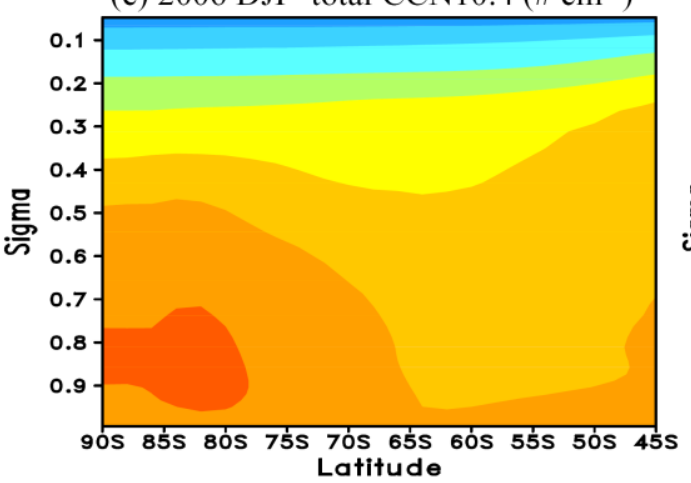

(g) 2006 DJF sea salt CCN0.4 (\# $\left.\mathrm{cm}^{-3}\right)$

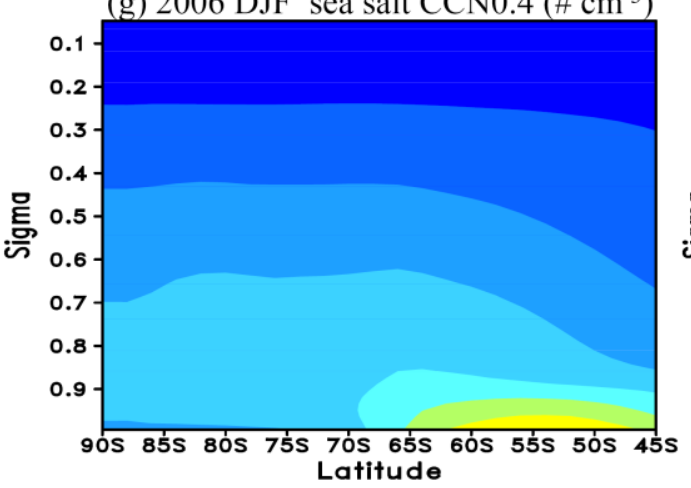

(b) 2006 JJA JIMN $\left(\# \mathrm{~cm}^{-3} \mathrm{~s}^{-1}\right)$

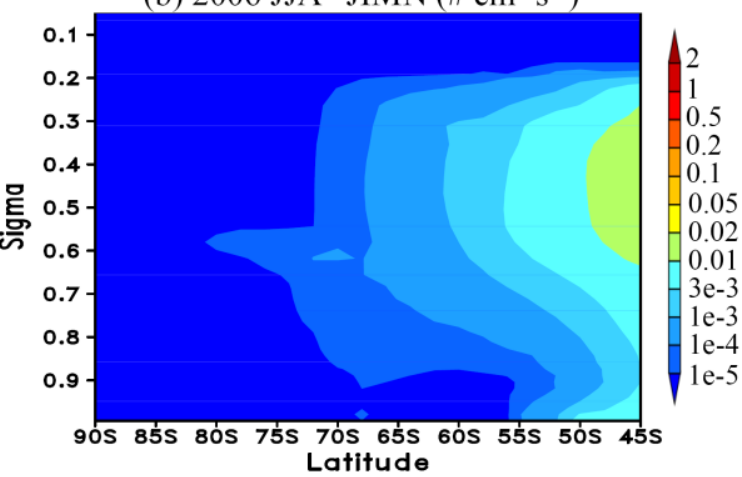

(d) 2006 JJA total CN10 $\left(\# \mathrm{~cm}^{-3}\right)$

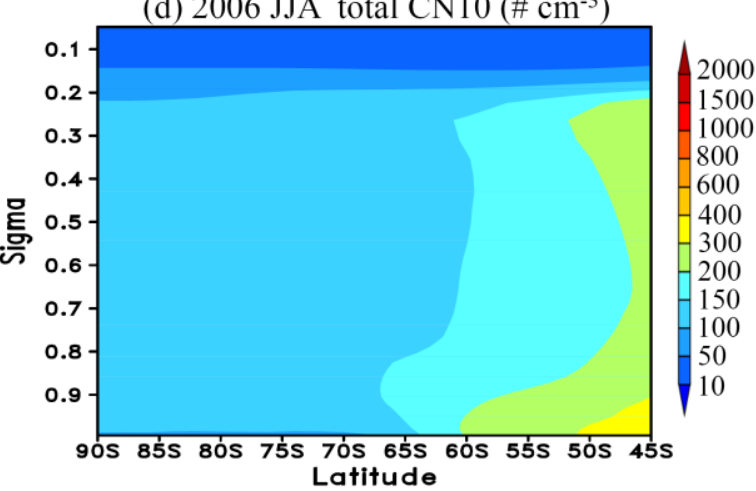

(f) $2006 \mathrm{JJA}$ total CCN0.4 $\left(\# \mathrm{~cm}^{-3}\right)$

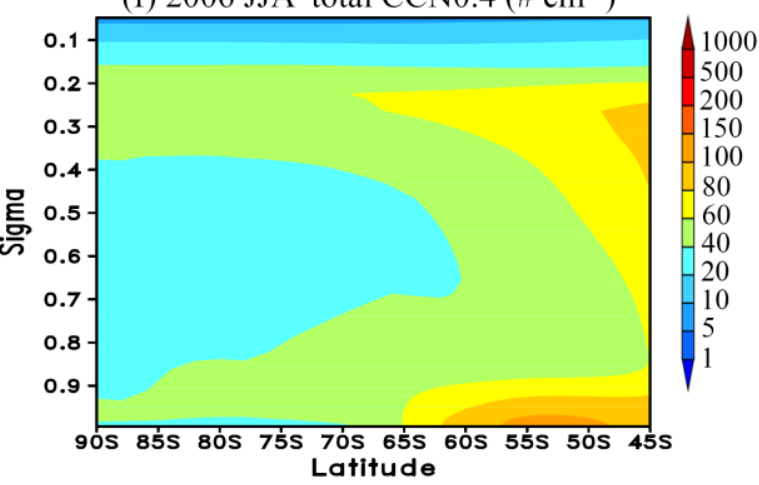

(h) 2006 JJA sea salt CCN0.4 $\left(\# \mathrm{~cm}^{-3}\right)$

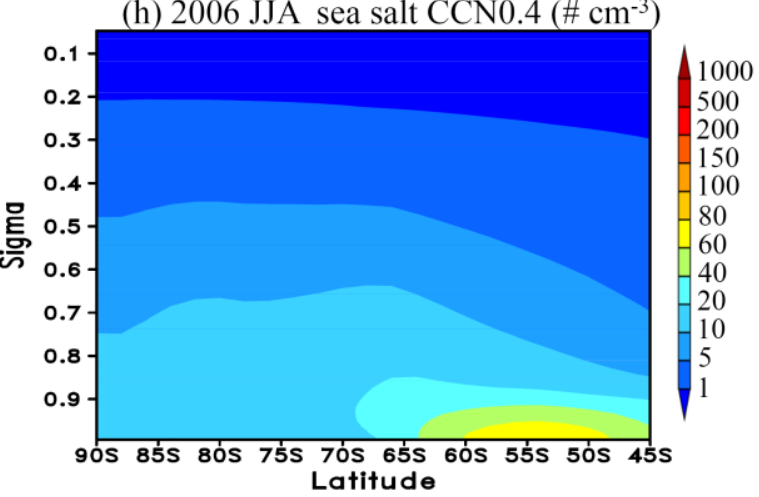


Table 1. A comparison of observed and simulated monthly mean CN10 values for different months of 2006 at the Neumayer station. Pearson correlation coefficient (r) and normalized mean bias (NMB) for four different modeling cases are also given.

\begin{tabular}{|c|r|r|r|r|r|}
\hline month & observation & $\begin{array}{c}\text { Case_ } \\
\text { baseline }\end{array}$ & $\begin{array}{c}\text { Case_ } \\
\text { DMS1.4 }\end{array}$ & $\begin{array}{c}\text { Case_ } \\
\text { DMS0.6 }\end{array}$ & $\begin{array}{r}\text { Case } \\
\text { BHN }\end{array}$ \\
\hline 1 & 643 & 685 & 798 & 468 & 76 \\
2 & 527 & 716 & 826 & 571 & 178 \\
3 & 564 & 358 & 398 & 283 & 112 \\
4 & 226 & 155 & 172 & 120 & 69 \\
5 & 149 & 101 & 109 & 91 & 67 \\
6 & 98 & 85 & 92 & 79 & 54 \\
7 & 91 & 73 & 79 & 68 & 50 \\
8 & 225 & 89 & 98 & 83 & 64 \\
9 & 224 & 116 & 159 & 97 & 66 \\
10 & 244 & 178 & 271 & 104 & 60 \\
11 & 377 & 495 & 646 & 267 & 107 \\
12 & 368 & 594 & 725 & 367 & 122 \\
\hline Average & 311 & 304 & 364 & 217 & 85 \\
\hline $\mathrm{r}$ & & 0.87 & 0.85 & 0.88 & 0.67 \\
\hline NMB & & -0.02 & 0.17 & -0.30 & -0.73 \\
\hline
\end{tabular}

Figure 5. Observed and simulated $\mathrm{CN} 10$ values in different months of 2006 at the Neumayer station. See text for details.

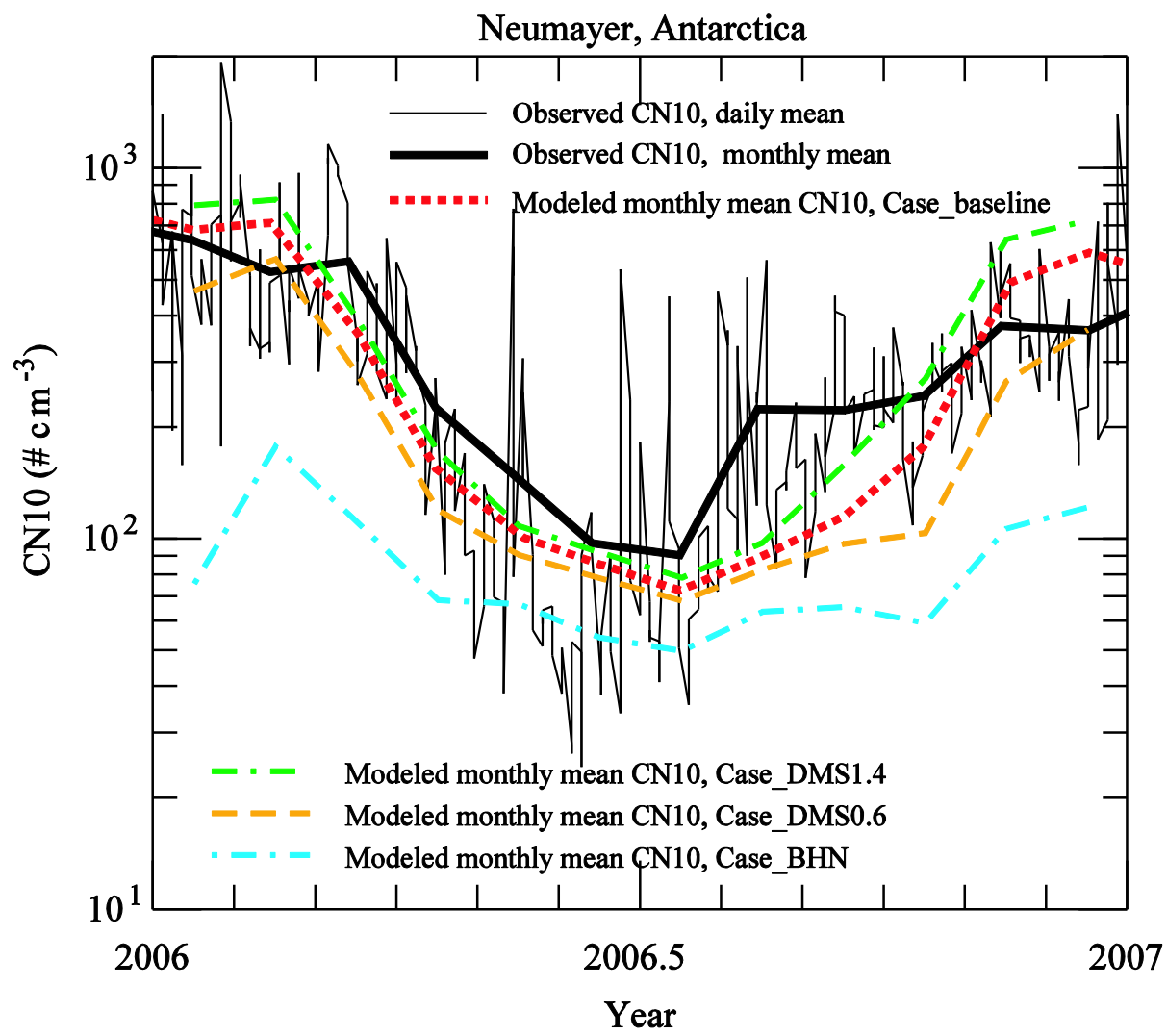


It is clear from Table 1 and Figure 5 that the baseline case gives the best overall agreement with observations ( $r=0.87, \mathrm{NMB}=-0.02)$. Increase/decrease of DMS emission by $40 \%$ only changes the $\mathrm{r}$ value slightly (from 0.87 to $0.85 / 0.88$ ) but influences the NMB value substantially (from -0.02 to $0.17 /(-0.30))$. Annual mean CN10 at the Neumayer station increases by $20 \%$ if global oceanic DMS emission increases by $40 \%$ (from $20.0 \mathrm{Tg} \mathrm{S} \mathrm{yr}^{-1}$ to $28.0 \mathrm{Tg} \mathrm{S} \mathrm{yr}^{-1}$ ) and decreases by $29 \%$ if global oceanic DMS emission decrease by $40 \%$ (from $20.0 \mathrm{Tg} \mathrm{S} \mathrm{yr}^{-1}$ to $12.0 \mathrm{Tg} \mathrm{S} \mathrm{yr}^{-1}$ ). Although the DMS climatology of Kettle et al. [40] used in GEOS-Chem is based in part on observations, the real DMS emission in different months may deviate substantially from this DMS climatology. As a result, at least some of the differences between observed and modeled CN10 values in different months (see Figures 3 and 5) could be attributed to the uncertainty in the DMS emission predicted in GEOS-Chem.

The DJF monthly mean BHN rate at the Neumayer station is $\sim 10^{-4} \mathrm{~cm}^{-3} \mathrm{hr}^{-1}$ (not shown) which is more than 6 orders of magnitude smaller than the corresponding IMN rate (see Figure $3 b$ ) and is completely negligible. Our predicted lack of BHN in the BL is consistent with previous analysis and modeling study [16,17]. The significant under-prediction of CN10 at the Neumayer station in Case_BHN indicates that the downward entrainment of new particles formed in the free troposphere is not bale to account for the $\mathrm{CN} 10$ values observed in the Antarctic BL, supporting our baseline case conclusion about the importance of IMN in the Antarctic BL.

\section{Summary}

The main objective of this study is to investigate the well-recognized seasonal variations of new particle formation around Antarctic coastal areas associated with DMS emissions by using a recently developed global size-resolved aerosol model and an ion-mediated nucleation (IMN) mechanism. Our simulations indicate that enhanced DMS emission, photochemistry, and $\left[\mathrm{H}_{2} \mathrm{SO}_{4}\right]$ during the austral summer season lead to significant new particle formation and much higher particle number concentrations. The predicted highest nucleation rates are confined around the coastline, which is consistent with measurements of ultrafine particle number concentrations. The seasonal mean concentration of the condensation nuclei larger than $3 \mathrm{~nm}(\mathrm{CN} 3)$ increases from $\sim 50-200 \mathrm{~cm}^{-3}$ in the austral winter (JJA) to above $\sim 2,000 \mathrm{~cm}^{-3}$ in the austral summer (DJF) in the surface layer around the Antarctic coastal areas. There also exist significant seasonal variations of the number concentrations of condensation nuclei larger than $10 \mathrm{~nm}(\mathrm{CN} 10)$ and cloud condensation nuclei at water supersaturation of $0.4 \%$ (CCN0.4). The analysis of vertical structures indicates that significant new particle formation over Antarctica in the austral summer extends from the boundary layer to $500 \mathrm{mb}$. While nucleation is generally inhibited in the marine boundary layer over the Southern Ocean due to the high concentration of sea salt particles, significant nucleation occurs above the MBL. From the austral winter to summer, the zonally averaged $\mathrm{CN} 10$ and CCN0.4 concentrations in the lower and middle troposphere over Antarctica increase by a factor of $\sim 4-6$ and $\sim 2-4$, respectively.

A comparison of the predicted CN10 during a three-year period (2005-2007) with the long-term continuous CN10 measurements at the German Antarctic station Neumayer shows that the model captures the absolute values of monthly mean CN10 (within a factor of 2-3) as well as their seasonal variations. Both model and observations indicate around a factor of 7 increase in seasonal mean CN10 from July to Janunary at the Neumayer station. Our model simulations clearly indicate that the 
observed CN10 seasonal variations are due to the formation of secondary particles during the austral summer associated with enhanced DMS emission and $\left[\mathrm{H}_{2} \mathrm{SO}_{4}\right]$. There are no obvious seasonal variations in the concentration of primary particles. Since the Neumayer station is almost free from anthropogenic pollutants and leafed plants and particle chemical composition analyses indicate that particles in Antarctic air mass are most acidic and consist primarily of sulfuric acid [18,19], it is reasonable to conclude that sulfuric acid dominates the particle formation and growth around the Antarctic regions. Our study appears to show that the IMN mechanism, which is based on state-of-theart thermodynamic and laboratory data [44], can account for the new particle formation frequently observed in the Antarctic region during the austral summer. The nice agreement of predicted seasonal variations of $\mathrm{CN} 10$ based on IMN mechanism with measurements during all the three simulated years provides a reasonable support for the IMN mechanism. Our sensitivity studies show strong impacts of DMS emissions on CN10 values around the Antarctica and downward transport of particles formed via binary homogeneous nucleation in the free troposphere has very small contribution to the $\mathrm{CN}$ abundance at the Neumayer station.

\section{Acknowledgements}

This study is supported by the NASA under grant NNX08AK48G and NSF under grant AGS-0942106. The GEOS-Chem model is managed by the Atmospheric Chemistry Modeling Group at Harvard University with support from the NASA Atmospheric Chemistry Modeling and Analysis Program.

\section{References and Notes}

1. Faloona, I. Sulfur processing in the marine atmospheric boundary layer: A review and critical assessment of modeling uncertainties. Atmos. Environ. 2009, 43, 2841-2854.

2. Charlson, R.J.; Lovelock, J.E.; Andreae, M.O.; Warren, S.G. Oceanic phytoplankton, atmospheric sulfur, cloud albedo and climate. Nature 1987, 326, 655-661.

3. Bopp, L.; Boucher, O.; Aumont, O.; Belviso, S.; Dufresne, J.L.; Pham, M.; Monfray, P. Will marine dimethylsulfide emissions amplify or alleviate global warming? A model study. Can. J. Fish. Aquat. Sci. 2004, 61, 826-835.

4. Gunson, J.R.; Spall, S.A.; Anderson, T.R.; Jones, A.; Totterdell, I.J.; Woodage, M.J. Climate sensitivity to ocean dimethylsulphide emissions. Geophys. Res. Lett. 2006, 33, L07701.

5. Kloster, S.; Six, K.D.; Feichter, J.; Maier-Reimer, E.; Roeckner, E.; Wetzel, P.; Stier, P.; Esch, M. Response of dimethylsulfide (DMS) in the ocean and atmosphere to global warming. J. Geophys. Res. 2007, 112, G03005.

6. Ayers, G.P.; Cainey, J.M. The CLAW hypothesis: a review of the major developments. Environ. Chem. 2007, 4, 366-374.

7. Hogan, A.W. Antarctic aerosols. J. App. Met. 1975, 14, 550-559.

8. Bigg, E.K.; Gras, J.L.; Evans, C. Origins of Aitken particles in remote regions of the southern hemisphere. J. Atmos. Chem. 1984, 1, 203-214.

9. Shaw, G.E. Antarctic aerosols: A review. Rev. Geophys. 1988, 26, 89-112. 
10. Jaenicke, R.; Dreiling, V.; Lehmann, E.; Koutsenoguii, P.K.; Stingl, J. Condensation nuclei at the German Antarctic station "Georg von Neumayer". Tellus. Ser. B 1992, 44, 311-317.

11. Ito, T. Size distribution of Antarctic submicron aerosols. Tellus. Ser. B 1993, 45, 145-159.

12. Gras, J.L. Condensation nucleus size distribution at Mawson, Antarctica: Microphysics and chemistry. Atmos. Environ., Part A 1993, 27, 1417-1425.

13. Koponen, I.K.; Virkkula, A.; Hillamo, R.; Kerminen, V.-M.; Kulmala, M. Number size distributions and concentrations of marine aerosols: Observations during a cruise between the English Channel and the coast of Antarctica. J. Geophys. Res. 2002, 107, 4753.

14. Koponen, I.K.; Virkkula, A.; Hillamo, R.; Kerminen, V.-M.; Kulmala, M. Number size distributions and concentrations of the continental summer aerosols in Queen Maud Land, Antarctica. J. Geophys. Res. 2003, 108, 4587.

15. Deshpande, C.G.; Kamra, A.K. Physical properties of aerosols at Maitri, Antarctica. Proc. Indian Acad. Sci. (Earth Planet Sci.) 2004, 113, 1-25.

16. Park, J.; Sakurai, H.; Vollmers, K.; McMurry, P.H. Aerosol size distributions measured at the South Pole during previous termISCATnext term 2000. Atmos. Environ. 2004, 38, 5493-5500.

17. Korhonen, H.; Carslaw, K.S.; Spracklen, D.V.; Mann, G.W.; Woodhouse, M.T. Influence of oceanic dimethyl sulfide emissions on cloud condensation nuclei concentrations and seasonality over the remote Southern Hemisphere oceans: A global model study. J. Geophys. Res. 2008, 113, D15204.

18. O’Dowd, C.D.; Lowe, J.A.; Smith, M.H.; Davison, B.; Hewitt, C.N.; Harrison, R.M. Biogenic sulphur emissions and inferred non-sea-salt-sulphate cloud condensation nuclei in and around Antarctica. J. Geophys. Res. 1997, 102, 12839-12854.

19. Virkkula, A.; Teinilä, K.; Hillamo, R.; Kerminen, V.-M.; Saarikoski, S.; Aurela, M.; Koponen, I. K.; Kulmala, M. Chemical size distributions of boundary layer aerosol over the Atlantic Ocean and at an Antarctic site. J. Geophys. Res. 2006, 111, D05306.

20. Asmi, E.; Frey, A.; Virkkula, A.; Ehn, M.; Manninen, H.E.; Timonen, H.; Tolonen-Kivimäki, O.; Aurela, M.; Hillamo, R.; Kulmala, M. Hygroscopicity and chemical composition of Antarctic submicrometre aerosol particles and observations of new particle formation. Atmos. Chem. Phys. 2010, 10, 4253-4271.

21. Spracklen, D.V.; Carslaw, K. S.; Kulmala, M.; Kerminen, V. M.; Sihto, S. L.; Riipinen, I.; Merikanto, J.; Mann, G. W.; Chipperfield, M. P.; Wiedensohler, A.; Birmili, W.; Lihavainen, H. Contribution of particle formation to global cloud condensation nuclei concentrations. Geophys. Res. Lett. 2008, 35, L06808.

22. Yu, F., Wang, Z.; Luo, G.; Turco, R.P. Ion-mediated nucleation as an important source of tropospheric aerosols. Atmos. Chem. Phys. 2008, 8, 2537-2554.

23. Makkonen, R.; Asmi, A.; Korhonen, H.; Kokkola, H.; Järvenoja, S.; Räisänen, P.; Lehtinen, K. E. J.; Laaksonen, A.; Kerminen, V.-M.; Järvinen, H.; Lohmann, U.; Bennartz, R.; Feichter, J.; Kulmala, M. Sensitivity of aerosol concentrations and cloud properties to nucleation and secondary organic distribution in ECHAM5-HAM global circulation model. Atmos. Chem. Phys. 2009, 9, 1747-1766.

24. Wang, M.; Penner, J.E. Aerosol indirect forcing in a global model with particle nucleation. Atmos. Chem. Phys. 2009, 9, 239-260. 
25. Pierce, J.R.; Adams, P.J. Uncertainty in global CCN concentrations from uncertain aerosol nucleation and primary emission rates. Atmos. Chem. Phys. 2009, 9, 1339-1356.

26. Merikanto, J.; Spracklen, D.V.; Mann, G.W.; Pickering, S.J.; Carslaw, K.S. Impact of nucleation on global CCN. Atmos. Chem. Phys. 2009, 9, 8601-8616.

27. Yu, F.; Luo, G. Simulation of particle size distribution with a global aerosol model: Contribution of nucleation to aerosol and CCN number concentrations. Atmos. Chem. Phys. 2009, 9, 7691-7710.

28. Yu, F.; Luo, G.; Bates, T.; Anderson, B.; Clarke, A.; Kapustin, V.; Yantosca, R.; Wang, Y.; Wu, S. Spatial distributions of particle number concentrations in the global troposphere: Simulations, observations, and implications for nucleation mechanisms. J. Geophys. Res. 2010, 115, D17205.

29. Vallina S.M.; Simó, R.; Gassó, S. What controls CCN seasonality in the Southern Ocean? A statistical analysis based on satellite-derived chlorophyll and $\mathrm{CCN}$ and model-estimated $\mathrm{OH}$ radical and rainfall. Global Biogeochem. Cycles 2006, 20, GB1014.

30. Meskhidze, N.; Nenes, A. Phytoplankton and cloudiness in the Southern Ocean. Science 2006, 314, 1419-1423.

31. Miller, M.A.; Yuter, S.E. Lack of correlation between chlorophyll a and cloud droplet effective radius in shallow marine clouds. Geophys. Res. Lett. 2008, 35, L13807.

32. Bey, I.; D. Jacob, J.; Yantosca, R.M; Logan, J. A.; Field, B.; Fiore, A. M.; Li, Q.; Liu, H.; Mickley, L. J.; Schultz, M. Global modeling of tropospheric chemistry with assimilated meteorology: Model description and evaluation. J. Geophys. Res. 2001, 106, 23073-23096.

33. Martin, R.V.; Jacob, D.J.; Yantosca, R.M.; Chin, M.; Ginoux, P. Global and regional decreases in tropospheric oxidants from photochemical effects of aerosols. J. Geophys. Res. 2003, 108, 4097.

34. Park, R. J.; Jacob, D. J.; Field, B. D.; Yantosca, R. M.; Chin, M. Natural and transboundary pollution influences on sulfate-nitrate-ammonium aerosols in the United States: Implications for policy. J. Geophys. Res. 2004, 109, D15204.

35. Evans, M.J.; Jacob, D.J. Impact of new laboratory studies of $\mathrm{N}_{2} \mathrm{O}_{5}$ hydrolysis on global model budgets of tropospheric nitrogen oxides, ozone, and OH. Geophys. Res. Lett. 2005, 32, L09813.

36. Nenes, A.; Seinfeld, J.H. Parameterization of cloud droplet formation in global climate models, $J$. Geoph. Res. 2003, 108, 4415.

37. Liao, H.; Henze, D.K.; Seinfeld, J.H.; Wu, S.; Mickley, L.J. Biogenic secondary organic aerosol over the United States: Comparison of climatological simulations with observations. J. Geophys. Res. 2007, 112, D06201.

38. Bond, T.C.; Bhardwaj, E.; Dong, R.; Jogani, R.; Jung, S.; Roden, C.; Streets, D. G.; Trautmann, N. M.. Historical emissions of black and organic carbon aerosol from energyrelated combustion, 1850-2000. Global Biogeochem. Cycles 2007, 21, GB2018.

39. Zhang, Q.; Streets, D.G.; Carmichael, G.R.; He, K.B.; Huo, H.; Kannari, A.; Klimont, Z.; Park, I. S.; Reddy, S.; Fu, J. S.; Chen, D.; Duan, L.; Lei, Y.; Wang, L. T.; Yao, Z. L. Asian emissions in 2006 for the NASA INTEX-B mission. Atmos. Chem. Phys. 2009, 9, 5131-5153.

40. Kettle, A.J.; Andreae, M. O.; Amouroux, D.; Andreae, T. W.; Bates, T. S.; Berresheim, H.; Bingemer, H.; Boniforti, R.; Curran, M. A. J.; DiTullio, G. R.; Helas, G.; Jones, G. B.; Keller, M. D.; Kiene, R. P.; Leck, C.; Levasseur, M.; Malin, G.; Maspero, M.; Matrai, P.; McTaggart, A. R.; Mihalopoulos, N.; Nguyen, B. C.; Novo, A.; Putaud, J. P.; Rapsomanikis, S.; Roberts, G.; Schebeske, G.; Sharma, S.; Simo, R.; Staubes, R.; Turner, S.; Uher, G. A global database of sea 
surface dimethylsulfide (DMS) measurements and a procedure to predict sea surface DMS as a function of latitude, longitude, and month. Glob. Biogeochem. Cycles 1999, 13, 399-444.

41. Nightingale, P.D.; Malin, G.; Law, C.S.; Watson, A.J.; Liss, P.S.; Liddicoat, M.I.; Boutin, J.; Upstill-Goddard, R.C. In situ evaluation of air-sea exchange parameterizations using novel conservative and volatile tracers. Global Biogeochem. Cycles 2000, 14, 373-387.

42. Woodhouse, M.T.; Carslaw, K.S.; Mann, G.W.; Vallina, S.M.; Vogt, M.; Halloran, P.R.; Boucher, O. Low sensitivity of cloud condensation nuclei to changes in the sea-air flux of dimethylsulphide. Atmos. Chem. Phys. 2010, 10, 7545-7559.

43. GEOS-Chem model webpage: http://acmg.seas.harvard.edu/geos (accessed on 2 July 2010).

44. Yu, F. Ion-mediated nucleation in the atmosphere: Key controlling parameters, implications, and look-up table. J. Geophy. Res. 2010, 115, D03206.

45. Luo, G.; Yu, F. A numerical evaluation of global oceanic emissions of alpha-pinene and isoprene. Atmos. Chem. Phys. 2010, 10, 20721-20738.

46. German Antarctic station Neumayer webpage: http://www.awi.de/en/infrastructure/stations/ neumayer_station (accessed on 12 October 2010).

47. König-Langlo, G.; King, J.C.; Pettré, P. Climatology of the three coastal Antarctic stations Dumont d'Urville, Neumayer, and Halley. J. Geophys. Res. 1998, 103, 10935-10946.

48. Weller, R.; Lampert, A. Optical properties and sulfate scattering efficiency of boundary layer aerosol at coastal Neumayer Station, Antarctica. J. Geophys. Res. 2008, 113, D16208.

49. Yu, F.; Turco, R.P. Case studies of particle formation events observed in boreal forests: Implications for nucleation mechanisms. Atmos. Chem. Phys. 2008, 8, 6085-6102.

50. Yu, F. Updated $\mathrm{H}_{2} \mathrm{SO}_{4}-\mathrm{H}_{2} \mathrm{O}$ binary homogeneous nucleation rate look-up tables. J. Geophy. Res. 2008, 113, D24201.

(C) 2010 by the authors; licensee MDPI, Basel, Switzerland. This article is an open access article distributed under the terms and conditions of the Creative Commons Attribution license (http://creativecommons.org/licenses/by/3.0/). 